\title{
Methanol extract of Hydroclathrus clathratus suppresses matrix metalloproteinase-9 in T24 bladder carcinoma cells by suppressing the NF- $\mathrm{KB}$ and MAPK pathways
}

\author{
R.G.P.T. JAYASOORIYA ${ }^{1}$, YUNG HYUN CHOI ${ }^{2}$, SUNG-KWON MOON $^{3}$, WUN-JAE KIM ${ }^{4}$ and GI-YOUNG KIM ${ }^{1}$ \\ ${ }^{1}$ Laboratory of Immunobiology, Department of Marine Life Sciences, Jeju National University, Jeju 690-756; \\ ${ }^{2}$ Department of Biochemistry, College of Oriental Medicine, Dongeui University, Busan 614-054; ${ }^{3}$ Department \\ of Food and Biotechnology, Chungju National University, Chungju, Chungbuk 380-702; ${ }^{4}$ Department of Urology, \\ College of Medicine, Chungbuk National University, Cheongju, Chungbuk 361-763, Republic of Korea
}

Received August 3, 2011; Accepted September 16, 2011

DOI: 10.3892/or.2011.1501

\begin{abstract}
Hydroclathrus clathratus is a brown marine seaweed and its extract possessing anti-cancer, anti-herpetic and anticoagulant activities is a traditional drug and health food in Korea, Japan and China. However, little is known about the mechanism by which the methanol extract of $H$. clathratus (MEHC) inhibits invasion of cancer cells. In the present study, we investigated the effects of MEHC on the expression of matrix metalloproteinase-9 (MMP-9) in T24 human bladder carcinoma cells. Our findings showed that MMP-9 activity was significantly increased in response to tumor necrosis factor- $\alpha$ (TNF- $\alpha$ ). However, treatment with MEHC substantially reversed TNF- $\alpha$-induced MMP-9 activity. A matrigel invasion assay also showed that MEHC reduced $\mathrm{TNF}-\alpha$-induced invasion of T24 bladder carcinoma cells. We also found that MEHC significantly downregulated the expression of the MMP-9 gene induced by TNF- $\alpha$ stimulation. Furthermore, we investigated the effects of MEHC on nuclear factor (NF)- $\kappa \mathrm{B}$ activity, which is a potential transcriptional factor for regulating many invasive genes including MMP-9. MEHC suppressed $\mathrm{NF}-\kappa \mathrm{B}$ activity by suppressing I $\kappa \mathrm{B}$ degradation and nuclear translocation of the NF- $\kappa \mathrm{B}$ p65 and p50 subunits. TNF- $\alpha$-induced phosphorylation of phosphatidyl-inositol 3 kinase (PI3K)/Akt and mitogen-activated protein kinase (MAPK) was significantly downregulated in the presence of MEHC. Taken together, these results indicate that MEHC is a potential anti-invasive agent by suppressing TNF- $\alpha$-induced cancer cell invasion and by specifically inhibiting $\mathrm{NF}-\kappa \mathrm{B}$ and MAPKs, as well as downstream target genes such as MMP-9.
\end{abstract}

Correspondence to: Professor Gi-Young Kim, Laboratory of Immunobiology, Department of Marine Life Sciences, Jeju National University, Jeju 690-756, Republic of Korea

E-mail: immunkim@jejunu.ac.kr

Key words: Hydroclathrus clathratus, matrix metalloproteinase-9, nuclear factor- $\mathrm{kB}$, phosphatidyl-inositol 3 kinase/Akt, mitogen-activated protein kinase

\section{Introduction}

Matrix metalloproteinases (MMPs) are zinc-dependent endopeptidases involved in the breakdown of the extracellular matrix under normal physiological conditions (1). According to recent studies, MMPs are also closely related to tumor invasion and metastasis by their capacity for tissue remodeling via the extracellular matrix as well as degradation of the basement membrane and induction of angiogenesis $(1,2)$. MMPs are mainly secreted as zymogens and cleaved to their active forms, and their functions are tightly regulated by several different mechanisms (3). One of them, MMP-9 is a key effector that promotes tumor cell invasion through type-IV collagen degradation-dependent extracellular matrix remodeling (4). MMP-9 expression has been observed in tumors of various organs, including the bladder, brain, liver, prostate and pancreatic carcinoma (5). In particular, elevated MMP-9 expression in bladder tumor tissues is correlated with tumor stage, grade and prognosis (6). Complications in most bladder cancers are attributed to metastasis to distant organs including the regional lymph nodes, liver, lungs, bone, adrenal glands and intestines (7). Therefore, a good strategy to treat bladder cancers is to target MMP-9 inhibition.

A recent study has shown that the nuclear factor $\kappa \mathrm{B}(\mathrm{NF}-\kappa \mathrm{B})$ and mitogen-activated protein kinase (MAPK) pathways tightly regulate MMP-9 expression in several types of cancer cells (8). $\mathrm{NF}-\kappa \mathrm{B}$ is normally located in the cytoplasm as an inactivated dimer composed of p65 and p50 subunits (9). In response to pro-inflammatory stimuli, I $\mathrm{B}$ is degraded by the phosphorylation and ubiqutination, and then $\mathrm{NF}-\kappa \mathrm{B}$ is released and translocated to the nucleus (10). Ultimately, $\mathrm{NF}-\kappa \mathrm{B}$ promotes the expression of tumor invasion-related genes such as MMP-9. The MAPKs are a group of signaling molecules that appear to play an important role in MMP expression. TNF- $\alpha$ stimulation is well known to result in the phosphorylation of p38, ERK and JNK leading to NF- $\kappa \mathrm{B}$ activation in bladder cancer cells and induces tumor invasion (8). Therefore, the NF- $\kappa \mathrm{B}$ and MAPK pathways are considered a good target to suppress MMP-9 expression to inhibit tumor invasion.

Hydroclathrus clathratus is a brown marine seaweed with anti-coagulant activity (11). The chemical constituents isolated 
from this seaweed are commonly polysaccharides H3-a1 and H3-b1, which have anti-viral and anti-cancer properties (12). Some components of $H$. clathratus affect the growth of human acute promyelocytic leukemia, human breast carcinoma and human hepatocellular carcinoma cancer cell lines (13). In particular, phenolic compounds isolated various seaweeds predominantly possess anti-inflammatory and anti-proliferative activities through radical scavenging activity (14). Though the total polyphenol contents of seaweeds are interesting to assess anti-inflammatory and anti-proliferative activities, no reports have evaluated the effects of $H$. clathratus on MMP-9 gene expression in cancer cells.

In this study, we evaluated the effects of a methanol extract of $H$. clathratus (MEHC) on MMP-9 expression in TNF- $\alpha$ stimulated T24 bladder carcinoma cells. We found that MEHC downregulated TNF- $\alpha$-induced MMP-9 mRNA and protein expression by suppressing NF- $\kappa \mathrm{B}$ activation and MAPK phosphorylation.

\section{Materials and methods}

Preparation of MEHC. MEHC was purchased from Jeju HI-Tech Industry Development Institute (Jeju, Republic of Korea). H. clathratus (stock no. AP060) was collected along the Jeju Island coast of Republic of Korea in July, 2006. Briefly, fresh $H$. clathratus was washed three times with tap water to remove salt, epiphyte and sand on the surface of the samples before storage $-20^{\circ} \mathrm{C}$. The frozen samples were lyophilized and homogenized using a grinder before extraction. The dried powder was extracted with $80 \%$ methanol and evaporated in vacuo.

Reagents. TNF- $\alpha$ and 3-(4,5-dimethylthiazol-2-yl)-2,5-diphenyl-tetrazolium bromide (MTT) were purchased from Sigma Chemical Co. (St. Louis, MO, USA). Polyclonal antibodies against MMP-9, p65, p50, I $\mathrm{B} \alpha$, ERK, phospho (p)-ERK, JNK, p-JNK p38, p-p38, phosphatidyl-inositol 3 kinase (PI3K), p-PI3K, Akt and p-Akt were purchased from Santa Cruz Biotechnology (Santa Cruz, CA, USA). Antibody against $\beta$-actin was obtained from Sigma. Roswell Park Memorial Institute medium (RPMI), antibiotics mixture and fetal bovine serum (FBS) were obtained from WelGENE Inc. (Daegu, Korea). Peroxidase-labeled goat anti-rabbit immunoglobulin was purchased from KOMA Biotechnology (Seoul). Other chemicals were purchased as Sigma grades.

Total polyphenol contents. Total polyphenol contents of MEHC were quantified according to the methods of Yuan et al (15). Sample absorbaces were read at $720 \mathrm{~nm}$. Gallic acid was used as the standard for a calibration curve. Total pholyphenol contents of the seaweed extracts were represented as gallic acid equivalents.

Cell culture and cell viability assay. T24 bladder carcinoma cells (ATCC, Rockville, MD, USA) were cultured at $37^{\circ} \mathrm{C}$ in $5 \% \mathrm{CO}_{2}$ in RPMI supplemented with $10 \% \mathrm{FBS}$ and antibiotics. In all experiments, cells were pretreated with MEHC $1 \mathrm{~h}$ before the addition of TNF- $\alpha(20 \mathrm{ng} / \mathrm{ml})$ in serum-free RPMI. Cell viability was determined by an MTT assay. In brief, T24 bladder carcinoma cells $\left(1 \times 10^{5}\right.$ cells $\left./ \mathrm{ml}\right)$ were plated onto 24 -well plates and incubated overnight. The cells were treated with the indicated concentrations of MEHC for $1 \mathrm{~h}$ and then stimulated with TNF- $\alpha(20 \mathrm{ng} / \mathrm{ml})$ for $24 \mathrm{~h}$. Then, the cells were incubated with a solution of $0.5 \mathrm{mg} / \mathrm{ml} \mathrm{MTT}$ and incubation for $45 \mathrm{~min}$ at $37^{\circ} \mathrm{C}$ and $5 \% \mathrm{CO}_{2}$. Supernatant was removed and the formation of formazan was observed by monitoring the signal at $540 \mathrm{~nm}$ using a microplate reader.

Isolation of total RNA and RT-PCR. Total RNA was extracted using easy-BLUE ${ }^{\mathrm{TM}}$ total RNA extraction kit (iNtRON Biotechnology; Sungnam, Korea) according to the manufacturer's instruction. RNA ( $2 \mu \mathrm{g})$ was reverse-transcribed using MMLV reverse transcriptase (Bioneer; Daejeon, Korea). cDNA was amplified by PCR using specific primer MMP-9 (forward 5'-gta ttt gtt caa gga tgg gaa ata c-3' and reverse 5'-gca gga tgt cat agg tca cgt ag-3') and GAPDH (forward 5'-cca ccc atg gca aat tcc at-3' and reverse 5'-tct aga cgg cag gtc agg tcc acc-3'). Reaction products were analyzed on $1.0 \%$ agarose gels, and the bands were visualized by ethidium bromide.

Western blot analysis. Total cell extracts were prepared using PRO-PREP protein extraction kit (iNtRON Biotechnology). The preparation of cytoplasmic or nuclear extracts was conducted using NE-PER cytosolic/nuclear extraction reagents (Pierce; Rockford, IL, USA). Cell extracts were separated on polyacrylamide gels and then standard procedures were used to transfer them to the nitrocellulose membranes. The membranes were developed using an ECL reagent (Amersham; Arlington Heights, IL, USA).

Electrophoretic mobility assay (EMSA). DNA-protein binding assays were carried out with nuclear extract. Synthetic complementary NF- $\mathrm{NB}\left(5^{\prime}\right.$-agt tga ggg gac ttt ccc agg c-3') binding oligonucleotides (Santa Cruz Biotechnology) were 3'-biotinylated using the biotin 3'-end DNA labeling kit (Pierce) according to the manufacturer's instructions and annealed for $30 \mathrm{~min}$ at room temperature. The reaction mixture was electrophoretically separated on a $4 \%$ polyacrylamide gel in $0.5 \mathrm{X}$ Tris-borate buffer and transferred to a nylon membrane. The transferred DNA was cross-linked to the membrane at $120 \mathrm{~mJ} / \mathrm{cm}^{2}$. Horseradish peroxidase-conjugated streptavidin was used according to the manufacturer's instructions to detect the transferred DNA.

Gelatin substrate gel zymography. T24 bladder carcinoma cells were incubated at $37^{\circ} \mathrm{C}$ in $5 \% \mathrm{CO}_{2}$ in serum-free RPMI medium supplemented with $10 \%$ FBS and antibiotics with or without MEHC for $24 \mathrm{~h}$. Supernatants were collected and then subjected to sodium dodecyl sulfate-polyacrylamide gel electrophoresis (SDS-PAGE) copolymerized with gelatin. After electrophoresis, the gels were washed several times with $2.5 \%$ Triton $\mathrm{X}-100$ for $1 \mathrm{~h}$ at room temperature to remove the SDS and then incubated for $24 \mathrm{~h}$ at $37^{\circ} \mathrm{C}$ in reaction buffer containing $5 \mathrm{mM} \mathrm{CaCl}_{2}$ and $1 \mu \mathrm{M} \mathrm{ZnCl}_{2}$. The gels were stained with $0.25 \%$ Coomassie blue for $30 \mathrm{~min}$ and then destained for $1 \mathrm{~h}$ in a solution of acetic acid and methanol. The proteolytic activity was evidenced as clear bands (zones of gelatin degradation) against the blue background of stained gelatin.

Matrigel invasion assay. T24 bladder carcinoma cells were trypsinized and $5 \times 10^{4}$ cells were placed onto matrigel-coated 


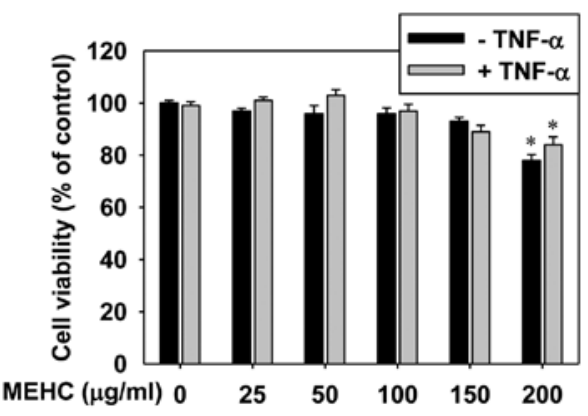

Figure 1. Effects of a methanol extract of Hydroclathrus clathratus (MEHC) on T24 cell viability. T24 bladder carcinoma cells $\left(1 \times 10^{5}\right.$ cells $\left./ \mathrm{ml}\right)$ were incubated with the indicated concentrations of MEHC $1 \mathrm{~h}$ before tumor necrosis factor (TNF)- $\alpha(20 \mathrm{ng} / \mathrm{ml})$ treatment for $24 \mathrm{~h}$. Cell viability was determined by the MTT assay. Each value indicates the mean $\pm \mathrm{SE}$, and is representative of results obtained from three independent experiments. "p $<0.05$ was considered significantly different from the values in cells with an untreated control.

transwell for $3 \mathrm{~h}$. The cells were treated with $100 \mu \mathrm{g} / \mathrm{ml}$ of MEHC for $1 \mathrm{~h}$ and then stimulated with TNF- $\alpha$ (20 ng/ml) for $24 \mathrm{~h}$. Then, the cells in the upper chamber were removed with a cotton swab. The cells that adhered on the outer surface of the transwell insert were fixed, stained with Coomassie blue, and counted under a light microscope.

Statistical analysis. All data were derived from at least three independent experiments. The images were visualized with Chemi-Smart 2000 (Vilber Lourmat; Marine, France). Images were captured using Chemi-Capt (Vilber Lourmat) and transported into Photoshop. Statistical analyses were conducted using SigmaPlot software (version 11.0). Values were presented as mean \pm SE. Significant differences between the groups were determined using two-way ANOVA. Statistical significance was regarded at $\mathrm{p}<0.05$.

\section{Results}

Effects of MEHC on cell viability. As assayed by gallic acid equivalents, total phenol contents represented $\sim 2.7 \pm 0.2 \%$ of MEHC. Next, in order to determine the effects of MEHC on cell viability in T24 bladder carcinoma cells, MTT assay was performed at $24 \mathrm{~h}$ after treatment with the indicated concentrations of MEHC in the presence or absence of TNF- $\alpha$. MEHC alone at $25-150 \mu \mathrm{g} / \mathrm{ml}$ showed no cytotoxic effects (Fig. 1), but significant cytotoxicity was found at $200 \mu \mathrm{g} / \mathrm{ml} \mathrm{MEHC}$, regardless of the presence of TNF- $\alpha$. DMSO (0.1\%) as a solvent had no cytotoxic effect (data not shown). Therefore, the concentration of MEHC was applied within this range for further experiments.

Suppressive effect of MEHC on MMP-9 activity. Zymography, the real-time polymerase chain reaction (RT-PCR) and Western blot assays were conducted to assess whether MEHC regulates MMP-9 expression. The zymography data showed that MEHC significantly suppressed TNF- $\alpha$-induced MMP-9 activity (Fig. 2A). We also found that MEHC significantly downregulated TNF- $\alpha$-induced MMP-9 mRNA and protein expression. In the Western blot analysis, TNF- $\alpha$ stimulation of cells resulted in a significant increase in MMP-9 expression
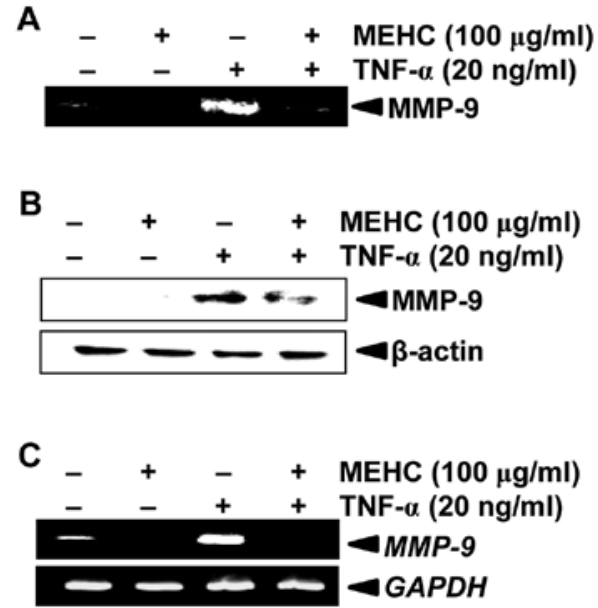

Figure 2. Effects of a methanol extract of Hydroclathrus clathratus (MEHC) on tumor necrosis factor (TNF)- $\alpha$-induced matrix metalloproteinase-9 (MMP-9) expression in T24 bladder carcinoma cells. (A) T24 cells were treated with $100 \mu \mathrm{g} / \mathrm{ml} \mathrm{MEHC} 1 \mathrm{~h}$ before TNF- $\alpha(20 \mathrm{ng} / \mathrm{ml})$ treatment for $24 \mathrm{~h}$. Conditioned medium was collected after $24 \mathrm{~h}$, followed by gelatin zymography. (B) Equal amounts of cell lysates were resolved on SDS-polyacrylamide gels, transferred to nitrocellulose membranes, and probed with antibodies against MMP-9. Cells were incubated with the indicated concentrations of MEHC $1 \mathrm{~h}$ before the TNF- $\alpha(20 \mathrm{ng} / \mathrm{ml})$ treatment for $24 \mathrm{~h}$. (C) Total RNA was isolated, and RT-PCR analysis of MMP-9 was performed. GAPDH and $\beta$-actin were used as internal controls for the RT-PCR and Western blot analysis, respectively. The experiment was repeated three times, and similar results were obtained.

compared to that in the untreated control (Fig. 2B). However, MEHC reversed TNF- $\alpha$-induced MMP-9 activity to the levels of the untreated control. Moreover, MMP-9 gene expression was confirmed by RT-PCR analysis. Pretreatment with MEHC significantly suppressed TNF- $\alpha$-induced $M M P-9$ upregulation at the mRNA level (Fig. 2C). Taken together, these results indicate that MEHC suppressed upregulation of TNF- $\alpha$-stimulated MMP-9 expression at the transcriptional level.

Inhibitory effect of MEHC on invasion of T24 bladder carcinoma cells. MMP-9 is thought to be critically involved in the processes of tumor invasion and angiogenesis (5). Because MEHC inhibited MMP-9 expression and activity, we examined the effects of MEHC on invasion of T24 bladder carcinoma cells (Fig. 3A). When the cells were treated with TNF- $\alpha$ alone, a remarkable 3 -fold higher increase in cell invasion was observed compared to that in the untreated control. However, MEHC pretreatment resulted in an $\sim 50 \%$ reduction in penetration through a matrigel-coated membrane compared to that in the TNF- $\alpha$-treated group (Fig. 3B). These results confirm that MEHC inhibited TNF- $\alpha$-induced invasion in T24 bladder carcinoma cells.

Inhibitory effects of MEHC on TNF- $\alpha$-induced $N F-\kappa B$ activity. We assessed the specific DNA-binding activity of $\mathrm{NF}-\kappa \mathrm{B}$ using an electrophoretic mobility shift assay (EMSA) to investigate whether MEHC inhibits MMP-9 activity by suppressing $\mathrm{NF}-\kappa \mathrm{B}$ activity. TNF- $\alpha$ stimulation caused a remarkable increase in binding complexes between $\mathrm{NF}-\kappa \mathrm{B}$ and specific-binding DNA at $30 \mathrm{~min}$; however, pretreatment with MEHC for $1 \mathrm{~h}$ significantly reduced TNF- $\alpha$-induced $N F-\kappa B$ 
A

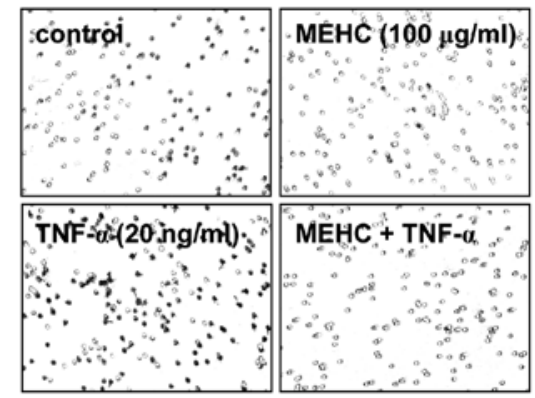

B

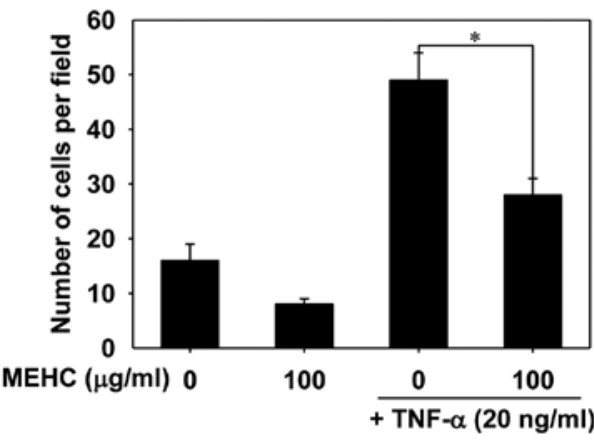

Figure 3. Suppressive effects of a methanol extract of Hydroclathrus clath ratus (MEHC) on invasion of T24 bladder carcinoma cells. (A) The upper parts of the transwells were coated with matrigel for the invasion assay. Then, the cells were cultured in serum-free media for $1 \mathrm{~h}$ before treatment with MEHC $(100 \mu \mathrm{g} / \mathrm{ml})$ in the absence or presence of tumor necrosis factor (TNF)- $\alpha(20 \mathrm{ng} / \mathrm{ml})$. After $24 \mathrm{~h}$, the numbers of cells passing through the matrigel to the membrane were dyed using $0.125 \%$ Coomassie blue in ethanol. (B) Data are expressed as overall mean $\pm \mathrm{SE}$ from three independent experiments, and the numbers of cells per field are estimated. Statistical significance was determined by two-way ANOVA test ( $\mathrm{p}<0.05$ vs. TNF- $\alpha$-treated group).

activity (Fig. 4A). In a parallel experiment, p65, p50 and IкB $\alpha$ expression levels in the cytoplasmic region were determined after TNF- $\alpha$ stimulation in the absence or presence of MEHC (Fig. 4B). TNF- $\alpha$ significantly decreased p65, p50 and IкB $\alpha$ expression in the cytoplasmic compartment of T24 bladder carcinoma cells. However, treatment with MEHC sustained the TNF- $\alpha$-induced expression of p65, p50 and IкB $\alpha$ (Fig. 4B). Because the PI3K and Akt signal pathways regulate NF- $\kappa B$ activity upstream, we evaluated whether MEHC regulates TNF- $\alpha$-induced phosphorylation of this signaling pathway. As expected, stimulation with TNF- $\alpha$ significantly induced PI3K and Akt phosphorylation; however, pretreatment with MEHC shifted the expression level of the untreated control (Fig. 4C). These results indicate that MEHC inhibited the suppression of NF- $\kappa \mathrm{B}$ activity by suppressing the PI3K/Akt signal pathway.

Inhibitory effects of MEHC on TNF- $\alpha$-induced MAPK phosphorylation. We next evaluated the effects of MEHC on TNF- $\alpha$-induced phosphorylation of ERK, p38 and JNK in T24 bladder carcinoma cells. The phosphorylation levels of the various MAPKs increased dramatically $30 \mathrm{~min}$ after stimulation with TNF- $\alpha$. MEHC significantly reduced TNF- $\alpha$ induced phosphorylation of ERK, p38 and JNK. However, non-phosphorylated ERK, p38 and JNK expression was unaffected by TNF- $\alpha$ and/or MEHC alone. These results indicate
A
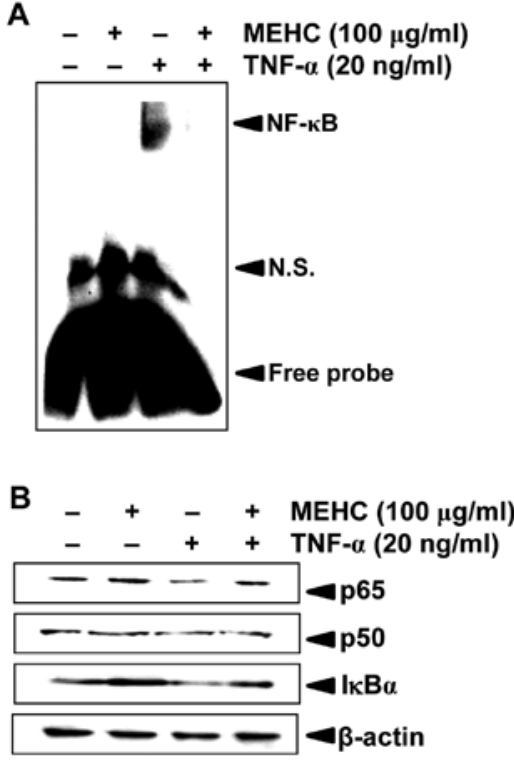

C

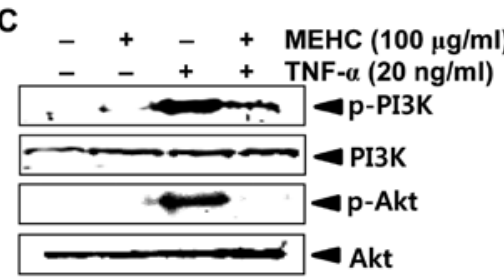

Figure 4. Effects of a methanol extract of Hydroclathrus clathratus (MEHC) on nuclear factor (NF)- $\kappa \mathrm{B}$ DNA binding activity. Cells were preincubated with MEHC $(100 \mu \mathrm{g} / \mathrm{ml}) 1 \mathrm{~h}$ before TNF- $\alpha(20 \mathrm{ng} / \mathrm{ml})$ stimulation for $30 \mathrm{~min}$. (A) Nuclear extracts were assayed for NF- $\mathrm{kB}$ activity using an electrophoretic mobility shift assay and (B) the levels of $\mathrm{p} 50$, IкB and $\mathrm{p} 65$ were analyzed by Western blot analysis. (C) In a parallel experiment, protein lysates were prepared, subjected to SDS-PAGE and immunoblotted using antibodies against $\mathrm{PI} 3 \mathrm{~K}, \mathrm{Akt}$ and their phosphorylated forms. $\beta$-actin was used as an internal control for Western blot assays. The experiment was repeated three times, and similar results were obtained. N.S., non-specific.

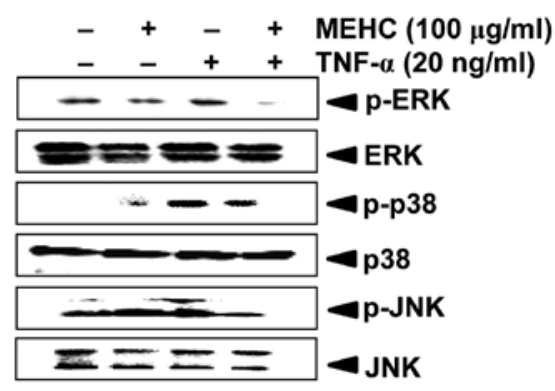

Figure 5. Effects of a methanol extract of Hydroclathrus clathratus (MEHC) on mitogen-activated protein kinases (MAPKs) in TNF- $\alpha$-stimulated T24 bladder carcinoma cells. T2 4 cells were pretreated with $100 \mu \mathrm{g} / \mathrm{ml}$ MEHC for $1 \mathrm{~h}$ and then incubated with TNF- $\alpha(20 \mathrm{ng} / \mathrm{ml})$ for $30 \mathrm{~min}$. Total cellular protein was resolved by SDS-PAGE, transferred to nitrocellulose membranes, and detected with specific antibodies against ERK, JNK, p38 and their phosphorylated forms. The experiment was repeated three times, and similar results were obtained. Statistical significance was determined by two-way ANOVA test ( ${ }^{*} \mathrm{p}<0.05$ vs. TNF- $\alpha$-treated group).

that MEHC may be involved in inhibiting MAPK activity to suppress TNF- $\alpha$-induced invasion (Fig. 5). 


\section{Discussion}

Our previous study suggested that MEHC considerably suppresses inflammatory responses such as lipopolysaccharideinduced pro-inflammatory cytokines and nitric oxide expression in BV2 microglia cells (unpublished data). It has also been reported that MEHC inhibits the proliferation of a variety of human cancer cells, including human breast carcinoma (MCF-7) and human hepatocellular carcinoma (13). Nevertheless, it is not fully known how MEHC regulates anti-cancer activity during the invasion process. Therefore, we determined that MEHC suppressed TNF- $\alpha$-induced NF- $\kappa B$ activity and this downregulation lead to decreased invasion of bladder cancer cells through the regulation of MMP-9. This study provides substantial evidence that MEHC contained common levels of phenol content compared to other seaweed ( $\sim 3 \%$ in extracts) and inhibited TNF- $\alpha$-induced MMP-9 expression in T24 bladder carcinoma cells by suppressing NF- $\mathrm{KB}$ activity through the PI3K/Akt and MAPK pathways.

Tumor metastasis is a multistep process by which a subset of individual cancer cells disseminates from a primary tumor to distant secondary organs or tissues. MMPs play a major role promoting tumor metastasis $(16,17)$. One of them, MMP-9, is regarded as a critical molecule to eliminate the progression of tumor invasion. Thus, the inhibitory effect of MMP-9 expression is important as a therapeutic experimental model of tumor invasion. Our results demonstrated that MEHC inhibited TNF- $\alpha$ induced MMP-9 activity accompanied by the suppression of MMP-9 gene transcription in T24 bladder carcinoma cells. Interestingly, the matrigel assay showed that MEHC suppressed cell invasion. MMP-9 is synthesized and secreted into the extracellular matrix as a late pro-enzyme, and the pro-peptide domain, containing a cysteine switch, interacts with zinc at the active site for enzyme activation by regulatory proteins such as tissue inhibitor of MMP (TIMP) and MT1-MMP (18-20). Therefore, whether MEHC-induced MMP-9 downregulation is regulated by TIMPs and MT1-MMP in the extracellular matrix needs to be investigated.

Several studies have identified the signal transduction pathways that are involved in regulating MMP-9 expression in tumor cells $(21,22)$. In particular, NF- $\mathrm{kB}$ is an important transcription factor for regulating the $M M P-9$ gene promoter and

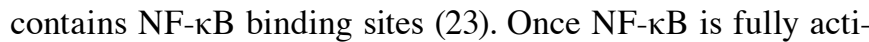
vated, it participates in the regulation of various target genes in different cells and is involved in various functions $(9,24)$. $\mathrm{NF}-\mathrm{\kappa B}$ is a heterodimer consisting of $\mathrm{p} 65$ and $\mathrm{p} 50$ proteins; it is located in the cytosol and is complexed with the IкB $\alpha$ inhibitory protein (25). A variety of extracellular signals including TNF- $\alpha$ and growth factors activate IкB kinase, which results in ubiquitination and degradation of IкB $\alpha$ by proteasomes and eventual dissociation of $\mathrm{I} \kappa \mathrm{B} \alpha$ from NF- $\mathrm{KB}$ (10). The activated $\mathrm{NF}-\mathrm{\kappa B}$ is then translocated to the nucleus where it binds to specific DNA sequences. Ultimately, NF- $\mathrm{kB}$ promotes the expression of various genes including MMP-9 (26). In this study, we showed that MEHC inhibited p65 and p50 protein translocation by suppressing IкB $\alpha$ degradation. However, the human MMP-9 promoter also contains two other transcription factors such as AP-1 and Sp1 $(27,28)$. In particular, AP-1 binding to the MMP-9 promoter region is thought to be important for regulating MMP-9 expression in response to phorbol 12-myristate 13-acetate (PMA); however, many researchers have reported that AP-1 activation is not involved in TNF- $\alpha$ stimulated MMP-9 expression (29,30). MMP-9 expression is also regulated by $\mathrm{Sp} 1$ in response to PMA and TNF- $\alpha(28,31)$. Therefore, further study is required to determine which transcriptional factors are inhibited in MEHC-induced MMP-9 downregulation.

We investigated whether MEHC inhibits PI3K and Akt phosphorylation, because PI3K and Akt are upstream regulators of NF-кB $(32,33)$. Treatment with MEHC suppressed $\mathrm{PI} 3 \mathrm{~K}$ and Akt phosphorylation. These data indirectly support the result that the TNF- $\alpha$-induced PI3K/Akt/NF-kB/MMP-9 pathway was inhibited by treatment with MEHC. In a previous study, Zhu et al reported that these signaling pathways are highly activated during the progression of chronic myeloid leukemia (34). Additionally, the role of MAPKs in the regulation of MMP-9 expression is particularly well understood in TNF- $\alpha$-stimulated cancer cells $(35,36)$. Some researchers have reported that TNF- $\alpha$-induced $\mathrm{p} 38$ is a MAPK effector that induces MMP-9 expression regardless of ERK1/2 and JNK $(35,36)$. In contrast, other have shown that TNF- $\alpha$ induces MMP-9 expression through AP-1-dependent ERK1/2 and/ or JNK activation (36). In this study, we found that MEHC suppressed TNF- $\alpha$-induced ERK, p38 and JNK phosphorylation, whereas non-phosphorylated ERK, p38 and JNK kinase expression was unaffected by MEHC treatment. Presumably, this discrepancy with previous studies was due to the cell types and specificity of the chemicals. In conclusion, our results showed that MEHC is a potent inhibitor of TNF- $\alpha$-induced MMP-9 expression and invasion by suppressing the PI3K/Akt/ NF-kB pathway.

\section{Acknowledgements}

This research was supported by Basic Science Research Program through the National Research Foundation of Korea (NRF) funded by the Ministry of Education, Science and Technology (no.: 2011-0001048).

\section{References}

1. Egeblad M and Werb Z: New functions for the matrix metalloproteinases in cancer progression. Nat Rev Cancer 2: 161-174, 2002 .

2. Konjevic G and Stankovic S: Matrix metalloproteinases in the process of invasion and metastasis of breast cancer. Arch Oncol 14: 136-140, 2006.

3. Stallings-Mann M and Radisky D: Matrix metalloproteinaseinduced malignancy in mammary epithelial cells. Cells Tissues Organs 185: 104-110, 2007.

4. Westermarck J and Kahari VM: Regulation of matrix metalloproteinase expression in tumor invasion. FASEB J 13: 781-792, 1999.

5. Saito N, Hatori T, Murata N, Zhang ZA, Ishikawa F, Nonaka H, Iwabuchi S and Samejima H: A double three-step theory of brain metastasis in mice: the role of the piamater and matrix metalloproteinases. Neuropathol Appl Neurobiol 33: 288-298, 2007.

6. Szarvas T, Vom Dorp F, Ergun S and Rubben H: Matrix metalloproteinases and their clinical relevance in urinary bladder cancer. Nat Rev Urol 8: 241-254, 2011.

7. Kanayama H: Matrix metalloproteinases and bladder cancer. J Med Invest 48: 31-43 2001.

8. Simon C, Goepfert H and Boyd D: Inhibition of the p38 mitogenactivated protein kinase by SB 203580 blocks PMA-induced Mr 92,000 type IV collagenase secretion and in vitro invasion. Cancer Res 58: 1135-1139, 1998. 
9. Miller SC, Huang R, Sakamuru S, Shukla SJ, Attene-Ramos MS, Shinn P, Van Leer D, Leister W, Austin CP and Xia M: Identification of known drugs that act as inhibitors of NF- $\kappa \mathrm{B}$ signaling and their mechanism of action. Biochem Pharmacol 79: 1272-1280, 2010.

10. Karin M and Ben-Neriah Y: Phosphorylation meets ubiquitination: the control of NF- $\mathrm{KB}$ activity. Annu Rev Immunol 18: 621-663, 2000

11. Wang H, Ooi VEC and Ang PO Jr: Antiviral polysaccharides isolated from Hong Kong brown seaweed Hydroclathrus clathratus. Sci China C Life Sci 50: 611-618, 2007.

12. Wang H, Ooi VEC and Ang PO Jr: Anti-herpesviral property and mode of action of a polysaccharide from brown seaweed (Hydroclathrus clathratus). World J Microbiol Biotechnol 26: 1703-1713, 2010.

13. Wang H, Chiu LCM, Ooi VEC and Ang PO Jr: A potent antitumor polysaccharide from the edible brown seaweed Hydroclathrus clathratus. Botanica Marina 53: 265-274, 2010

14. Yuan YV and Walsh NA: Antioxidant and antiproliferative activities of extracts from a variety of edible seaweeds. Food Chem Toxicol 44: 1144-1150, 2006

15. Yuan YV, Bone DE and Carrington MF: Extracts from dulse (Palmaria palmate) are effective antioxidants and inhibitors of cell proliferation in vitro. Food Chem Toxicol 43: 1073-1081, 2005.

16. Chabottaux V and Noel A: Breast cancer progression: insights into multifaceted matrix metalloproteinases. Clin Exp Metastasis 24: 647-656, 2007.

17. Sternlicht MD and Werb Z: How matrix metalloproteinases regulate cell behavior. Annu Rev Cell Dev Biol 17: 463-516, 2001.

18. Migita K, Eguchi K, Kawabe Y, Ichinose Y, Tsukada T, Aoyagi T, Nakamura $\mathrm{H}$ and Nagataki S: TNF- $\alpha$-mediated expression of membrane-type matrix metalloproteinase in rheumatoid synovial fibroblasts. Immunology 89: 553-557, 1996.

19. Visse R and Nagase H: Matrix metalloproteinases and tissue inhibitors of metalloproteinases. Cir Res 92: 827-839, 2003.

20. Nagase H, Visse R and Murphy G: Structure and function of matrix metalloproteinases and TIMPs. Cardiovasc Res 69 562-573, 2006

21. Friedel G, Pastorino U, Ginsberg RJ, Goldstraw P, Johnston M, Pass H, Putnam JB and Toomes H: Results of lung metastasectomy from breast cancer: prognostic criteria on the basis of 467 cases of the International Registry of Lung Metastases. Eur J Cardiothorac Surg 22: 335-344, 2002.

22. Lee SJ, Park SS, Lee US, Kim WJ and Moon SK: Signaling pathway for TNF- $\alpha$-induced MMP-9 expression: mediation through p38 MAP kinase, and inhibition by anti-cancer molecule magnolol in human urinary bladder cancer 5637 cells. Int Immunopharmacol 8: 1821-1826, 2008.

23. Eberhardt W, Huwiler A, Beck KF, Walpen S and Pfeilschifter J: Amplification of IL-1 beta-induced matrix metalloproteinase- 9 expression by superoxide in rat glomerular mesangial cells is mediated by increased activities of NF- $\mathrm{BB}$ and activating protein-1 and involves activation of the mitogen-activated protein kinase pathways. J Immunol 165: 5788-5797, 2000.
24. Epinat JC and Gilmore TD: Diverse agents act at multiple levels to inhibit the Rel/NF- $\mathrm{kB}$ signal transduction pathway. Oncogene 18: 6896-6909, 1999.

25. Li X and Stark GR: NF-кB-dependent signaling pathways. Exp Hematol 30: 285-296, 2002.

26. Kim HS, Kim HJ, Park KG, Kim YN, Kwon TK, Park JY, Lee KU, Kim JG and Lee IK: Alpha-lipoic acid inhibits matrix metalloproteinase-9 expression by inhibiting NF- $\kappa \mathrm{B}$ transcriptional activity. Exp Mol Med 39: 106-113, 2007.

27. Kuppers DA, Lan K, Knight JS and Robertson ES: Regulation of matrix metalloproteinase 9 expression by Epstein-Barr virus nuclear antigen 3C and the suppressor of metastasis Nm23-H1. J Virol 79: 9714-9724, 2005.

28. Taheri $\mathrm{F}$ and Bazan HE: Platelet-activating factor overturns the transcriptional repressor disposition of $\mathrm{Sp} 1$ in the expression of MMP-9 in human corneal epithelial cells. Invest Ophthalmol Vis Sci 48: 1931-1941, 2007.

29. Yeung $O$ and Hurta RA: Phorbol ester tumour promoter mediated altered expression and regulation of matrix metalloproteinase-2 in a H-ras transformed cell line capable of benign tumour formation. Mol Cell Biochem 220: 39-48, 2001.

30. Ray A, Bal BS and Ray BK: Transcriptional induction of matrix metalloproteinase-9 in the chondrocyte and synoviocyte cells is regulated via a novel mechanism: evidence for functional cooperation between serum amyloid A-activating factor-1 and AP-1. J Immunol 175: 4039-4048, 2005.

31. Shin SY, Kim JH, Baker A, Lim Y and Lee YH: Transcription factor Egr-1 is essential for maximal matrix metalloproteinase-9 transcription by tumor necrosis factor-alpha. Mol Cancer Res 8: 507-519, 2010.

32. Lee CW, Lin CC, Lin WN, Liang KC, Luo SF, Wu CB, Wang SW and Yang CM: TNF-alpha induces MMP-9 expression via activation of Src/EGFR, PDGFR/PI3K/Akt cascade and promotion of $\mathrm{NF}-x \mathrm{~B} / \mathrm{p} 300$ binding in human tracheal smooth muscle cells Am J Physiol Lung Cell Mol Physiol 292: 799-812, 2007.

33. Dan HC, Cooper MJ, Cogswell PC, Duncan JA, Ting JP and Baldwin AS: Akt-dependent regulation of NF- $x$ B is controlled by mTOR and Raptor in association with IKK. Genes Dev 22: 1490-1500, 2008

34. Zhu X, Zhang LW, Jing BZ, Dou $X$ and Zhao RC: TGF- $\beta 1-$ induced $\mathrm{PI} 3 \mathrm{~K} / \mathrm{Akt} / \mathrm{NF}-\varkappa \mathrm{B} / \mathrm{MMP}$ signaling pathway is activated in Philadelphia chromosome-positive chronic myeloid leukemia hemangoblasts. J Biochem 149: 405-414, 2011.

35. Cohen M, Meisser A, Haenggeli L and Bischof P: Involvement of MAPK pathway in TNF-alpha-induced MMP-9 expression in human trophoblastic cells. Mol Hum Reprod 12: 225-232, 2006.

36. Lee SO, Jeong YJ, Im HG, Kim CH, Chang YC and Lee IS: Silibinin suppresses PMA-induced MMP-9 expression by blocking the AP-1 activation via MAPK signaling pathways in MCF-7 human breast carcinoma cells. Biochem Biophys Res Commun 354: 165-171, 2007. 